NBER WORKING PAPER SERIES

FINANCIAL AID POLICY: LESSONS FROM RESEARCH

\author{
Susan Dynarski \\ Judith Scott-Clayton \\ Working Paper 18710 \\ http://www.nber.org/papers/w18710
NATIONAL BUREAU OF ECONOMIC RESEARCH
1050 Massachusetts Avenue
Cambridge, MA 02138
January 2013

Funding for this research provided by The Future of Children, a collaboration of the Woodrow Wilson School of Public \& International Affairs at Princeton University and the Brookings Institution" and the Bill \& Melinda Gates Foundation. The views expressed herein are those of the authors and do not necessarily reflect the views of the National Bureau of Economic Research.

NBER working papers are circulated for discussion and comment purposes. They have not been peerreviewed or been subject to the review by the NBER Board of Directors that accompanies official NBER publications.

(C) 2013 by The Trustees of Princeton University, circulated with permission. All rights reserved. Short sections of text, not to exceed two paragraphs, may be quoted without explicit permission provided that full credit, including $(\mathcal{C}$ notice, is given to the source. 
Financial Aid Policy: Lessons from Research

Susan Dynarski and Judith Scott-Clayton

NBER Working Paper No. 18710

January 2013

JEL No. I22,I23,I28

\begin{abstract}
$\underline{\text { ABSTRACT }}$
In the nearly fifty years since the adoption of the Higher Education Act of 1965, financial aid programs have grown in scale, expanded in scope, and multiplied in form. As a result, financial aid has become the norm among college enrollees. The increasing size and complexity of the nation's student aid system has generated questions about effectiveness, heightened confusion among students and parents, and raised concerns about how program rules may interact. In this article, we review what is known and what is not known about how well various student aid programs work. We find evidence that lowering costs can improve college access and completion, but this general rule is not without exception. For example, the complexity of program eligibility and delivery appears to moderate the impact of aid, and for students who have already decided to enroll, grants that link financial aid to academic achievement appear to boost college outcomes more than do grants with no strings attached. Future research is likely to focus on several issues: the importance of program design and delivery, whether there are unanticipated interactions between programs, and to what extent program effects vary across different types of students.
\end{abstract}

\author{
Susan Dynarski \\ University of Michigan \\ Weill Hall \\ 735 South State Street \\ Ann Arbor, MI 48109-3091 \\ and NBER \\ dynarski@umich.edu \\ Judith Scott-Clayton \\ Teachers College \\ Columbia University \\ 525 W.120th Street, Box 174 \\ New York, NY 10027 \\ and NBER \\ scott-clayton@tc.columbia.edu
}


On November 8, 1965, President Lyndon Johnson signed into law the Higher Education Act of 1965, which firmly established the federal government as the primary provider of financial aid for college. In his remarks that day at Southwestern Texas State College, his alma mater, President Johnson said, "To thousands of young men and women, this act means the path of knowledge is open to all that have the determination to walk it.... It means that a high school senior anywhere in this great land of ours can apply to any college or any university in any of the 50 States and not be turned away because his family is poor."1

In the nearly fifty years that have passed since the Higher Education Act was adopted, college enrollment has expanded dramatically and average aid per student has grown even faster (figure 1). ${ }^{2}$ Full-time-equivalent undergraduate enrollment more than doubled, from about 6.2 million in 1971-72 to 14.2 million in 2010-11, while average aid per student more than tripled, from $\$ 3,437$ to $\$ 12,455$ (in constant 2010 dollars). ${ }^{3}$ The increase in aid per student is driven primarily by the expanding reach of the federal programs, which now flow to a more diverse range of students than was anticipated when the programs were first conceived. The early programs were squarely focused on "traditional" students—young, recent high school graduates enrolled in college on a full-time basis. Federal aid, delivered primarily b the U.S. Department of Education was also focused on students with fairly low incomes. Government aid for students was delivered primarily by the U.S. Department of Education. ${ }^{4}$

[Figure 1 near here]

On all of these dimensions, student aid has undergone a transformation. Aid now flows not only to traditional college students, but also to part-time students, older students, and students who never graduated from high school. Today, aid is available not only to low-income students but 
also to middle-class (and even high-income) families, in the form of subsidized loans and tax credits. And government aid is provided not only by the U.S. Department of Education but also by the U.S. Department of Treasury and by state governments. Several other forms of government support, including work-study programs, and private aid are also available. Altogether, aid to undergraduates students totaled nearly \$190 billion in the 2010-11 school year, with the majority of aid (\$147 billion) coming from government sources.

The growing magnitude of government expenditures on student aid has justified growing interest in its effectiveness. Policy makers and taxpayers want to know the returns on their enormous investment: does student aid really influence educational outcomes? Or does it simply subsidize students for doing what they would have done anyway? The increasing variety in the forms taken by aid, in the students who receive it, and in the agents who deliver it has made it increasingly difficult to give a simple answer to the question of aid effectiveness.

Forty years ago, the main question asked about student aid was "Does it work?"-with "it" generally meaning Pell Grants and "work" generally referring to increases in initial college enrollments. Now, to understand the effectiveness of student aid, one needs to consider the wide array of grants, loans, and tax benefits administered by multiple agencies and levels of government. But to the extent that the form, design, and delivery of aid matter - as all evidence indicates they do - it may be difficult to extrapolate the effects of one program to another. Similarly, as college enrollments have risen, policy makers increasingly ask not just whether aid increases initial enrollment, but also whether it increases persistence, performance, and completion, as well as whether it affects choices about where to attend, what to study, and what 
to do after graduation. Thus, asking whether aid "works" now depends on both which program and which outcome is examined. In some cases, researchers do not have definitive answers, but can only make educated guesses about effectiveness based on related evidence from similar programs.

Moreover, students today are a much more heterogeneous group than they were forty years ago, and the effect of a given program may vary by student characteristics such as income, age, and family status. Whether aid "works" may depend on who is receiving the aid and what outcomes they aim to achieve through postsecondary education. Coaxing an eighteen-year-old high school graduate into enrolling full-time at a four-year college is a very different task from encouraging a thirty-five-year-old displaced worker to enroll in a part-time certificate program to strengthen her job skills. The same form of federal aid—Pell Grants—-funds both types of schooling for both populations, yet it may well be that Pell Grants are more effective in one case than the other. Where the evidence allows, we discuss heterogeneity in the effects of programs across groups of students who differ in age, income, or educational background, but in most cases the available evidence focuses only on average program effects.

Finally, the explosion in the variety and reach of student aid implies that the environment in which students and families make their decisions is increasingly complex. With dozens of tax and aid programs available, two-thirds of students are now eligible for some sort of discount on their college costs. ${ }^{5}$ For these students, the net price of college (tuition and fees less any grant aid) differs from its sticker price. In fact, despite steadily rising tuition prices, net prices were lower in 2010-2011 than they were in 2005-2006. ${ }^{6}$ It is tuition prices, however, that make 
headlines, in part because they are so much easier to communicate than net price. With the proliferation of aid and tax programs, families cannot easily know in advance how much college costs. Misperceptions about the real cost may be particularly consequential for first-generation college students, whose families have no experience with the aid system. Research shows that students are often unaware of the aid for which they are eligible and that they estimate tuition costs to be two to three times higher than the true levels. ${ }^{7}$ If families do not know about a price subsidy, they cannot respond to it.

In this article, we describe the evolution of student aid over the past few decades, focusing on the largest programs and providing a broad overview of the rest. We then discuss whether these programs increase college enrollment, persistence, and completion (the central measures of effectiveness about which we have the most evidence), noting impacts on other outcomes where available. We first spend some time laying out the methodological challenges facing researchers in this arena, in part to explain why the evidence is sometimes so thin. We then offer some lessons about student aid policy that we believe are supported by the existing evidence. We close with a discussion of the remaining gaps in knowledge about the effectiveness of student aid.

\section{The Changing Landscape of Financial Aid}

The major programs that subsidize college costs for undergraduates are listed in table 1, together with the totals for each program (adjusted for inflation and expressed in 2010 dollars) for selected years between 1990 and 2010. The federal loan programs and the Pell Grant were the two largest sources of aid for college throughout this period. Loans have grown more rapidly than grants: loan volume was five times higher in 2010 than in 1990, while Pell volume was four 
times higher. Grants from colleges are the third largest source of aid; they more than tripled over this period. The education tax benefits came on the scene in the late 1990s and are now a major source of funding for college. The reasons for the particularly large increase in the federal aid programs between 2005-06 and 2010-11 are discussed in detail in the next section.

[Table 1 near here]

The federal programs established in Title IV of the Higher Education Act of 1965 are known collectively as "Title IV aid" and include the precursors to Pell Grants, Stafford Loans, and Federal Work-Study. Title IV aid also includes a variety of smaller programs that have waxed and waned over the years. The following discussion focuses on the largest sources of government aid in table 1: Pell Grants, federal loans, education tax benefits, and state grant programs.

\section{[B]The Pell Grant}

The Higher Education Act of 1965 established the Educational Opportunity Grant Program, which allocated funds directly to colleges that committed to identifying and recruiting students with "exceptional financial need." ${ }^{8}$ In 1972, the program was split into the Supplemental Educational Opportunity Grant (SEOG) program, a relatively small program that delivers funds directly to colleges, and the Basic Educational Opportunity Grant (BEOG) program, which delivers funds directly to students. The BEOG program, renamed the Pell Grant in 1980 after Senator Claiborne Pell of Rhode Island, expanded eligibility to students attending part time, as well as to those in vocational education or community colleges. Between 1972 and 1992, college enrollments rose by 44 percent, but the number of Pell Grant recipients grew twentyfold as a 
result of these more generous eligibility criteria. ${ }^{9}$ Many of these new Pell recipients were adults returning to school: the proportion of recipients classified as independent (age twenty-four or older, married, or with children of their own) grew over this period from just 13 percent to 60 percent, where it remains today. ${ }^{10}$ As noted in the article in this volume by Sandy Baum and her colleagues, the proportion of Pell recipients who are over age 30 has tripled over the past 30 years, from 8 percent in the late 1970 s to 24 percent in $2009-10 .^{11}$

While there is no explicit income limit on Pell receipt, the vast majority of recipients have family incomes below $\$ 50,000$, which in 2010 was slightly above the median of U.S. household incomes. ${ }^{12}$ The definition of who is "needy" under the Pell rules has occasionally shifted, sweeping into Pell eligibility students from the middle of the income distribution. Some of these shifts resulted from explicit efforts to open the program to a wider range of incomes: the Middle Income Student Assistance Act of 1978, as its name suggests, expanded eligibility for Pell Grants to middle-income families. More subtly, increases in the maximum Pell grant award (the usual focus of legislative debates over Title IV funding) bump up the average grant of current recipients but also expand eligibility for the Pell further up the income distribution. This dynamic has been clear in recent years, when the Pell maximum rose substantially, from $\$ 4,689$ in $2008-$ 09 to $\$ 5,550$ in 2010-11 (in constant 2010 dollars). Over the same period, during which median family incomes were dropping, the share of Pell recipients with income over $\$ 50,000$ rose from 6 percent to 9 percent. $^{13}$

Figure 2 shows changes over time in the number of Pell recipients and the average Pell award among recipients. Adjusting for inflation, the average Pell Grant was flat or decreasing for most 
of the period between 1976-77 and 1995-96, but large increases since 2008 have raised the average Pell award to a historic high of $\$ 3,828$. Even these large recent increases, however, have barely kept pace with rising tuition prices: the "purchasing power" of the Pell actually declined slightly from 33 percent of public four-year tuition in 2008-09 to 32 percent in 2011-12. ${ }^{14}$

[Figure 2 near here]

In 2008, legislation was passed that increased the maximum grant and expanded summer awards. These changes, combined with higher college enrollments and weak economic conditions that pushed more families into Pell eligibility, drove Pell expenditures to record levels. Pell volume increased by more than 90 percent between 2008-09 and 2010-11, with the number of recipients rising from 6.2 million to 9.1 million and the average grant among recipients increasing from $\$ 2,945$ to $\$ 3,828 .^{15}$

\section{Federal Loans}

The Stafford Loan, the largest student loan program, was named after Vermont senator and education advocate Robert T. Stafford in 1988, but it dates to 1965, when the guaranteed student loan program was introduced. In the original program, the government paid the interest on these loans during college, loans were limited to low-income students, and loan volume was only a third of grant volume. The first spike in loan volume followed enactment of the Middle Income Student Assistance Act of 1978, which opened eligibility for subsidized loans to all undergraduates, regardless of need. ${ }^{16}$ Loan volume exploded, as families seeking cheap creditinterest rates on mortgages hovered around 15 percent at the time-flooded into the student loan 
program. The need requirement on subsidized loans was reinstated in 1981 to contain ballooning costs.

Changes to the loan program in 1992 resulted in a sharp uptick in volume and unabated growth over the following twenty years. In 1992, an unsubsidized version of Stafford Loans was created, open to all students regardless of need. The government does not pay the interest on unsubsidized Stafford Loans while students are enrolled, but both subsidized and unsubsidized Stafford loans offer interest rates, forbearance protections, and flexible repayment options that make them substantially more appealing than private student loans. Dependent students are allowed to borrow $\$ 31,000$ in federal loans over the course of their undergraduate career. For those deemed sufficiently needy, $\$ 23,000$ of this total can take the form of subsidized loans. A student cannot take out this full amount in a single year; there are also annual limits on borrowing (of $\$ 2,625$ to $\$ 7,500$ depending upon the student's undergraduate standing).

Starting in 1992, parents also were allowed to borrow up to the full cost of attendance, including room and board for full-time students, through PLUS loans, which had been established in 1980 (before 1992, these loans were capped at \$4,000). These loans are open to the parents of all college students, regardless of need. Unlike Stafford Loans, PLUS loans require a credit check. Parents are responsible for loan payments, which begin immediately. Over half of college loans initiated each year are now through the PLUS and unsubsidized Stafford Loan programs. ${ }^{17}$

Rising levels of student debt have raised fears among some commentators of a "higher education bubble" that may be exposing taxpayers to higher-than-recognized default risks, akin to the housing bubble that preceded the financial crisis of $2008 .{ }^{18}$ The aggregate volume of outstanding 
student loans (both federal and private) surpassed \$1 trillion in late 2011. This figure, which has received considerable press attention, nonetheless should be viewed in the context of an expanding population of current and former college students. ${ }^{19}$ On a per-student basis, average

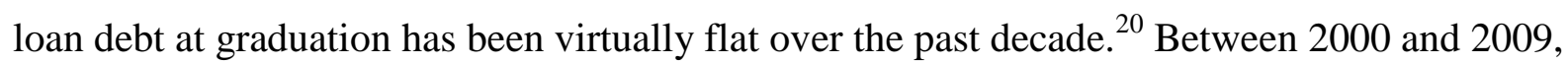
the share of graduates with loans has remained stable at 65 percent, and the average cumulative debt among borrowers has held steady at around $\$ 25,000 .{ }^{21}$ Ninety percent of students who receive bachelor's degrees graduate with less than $\$ 40,000$ of debt, and approximately one-third borrow nothing at all. ${ }^{22}$

Compared with other graduates, those with more than $\$ 40,000$ in undergraduate debt are 20 percentage points more likely to have attended schools costing $\$ 20,000$ or more a year (including room and board), and 20 percentage points less likely to have attended a public institution. Ten percent attended a private for-profit institution, compared with only 1 percent of their lesserborrowing peers. News articles tend to focus on the most extreme cases, such as graduates with $\$ 100,000$ in debt. However, only 0.1 percent of college entrants, and 0.3 percent of bachelor's degree recipients, accumulate more than $\$ 100,000$ in undergraduate student debt. ${ }^{23}$

\section{Tax Benefits for Education}

In the late 1990s, the federal government began using the tax code to subsidize college costs. The largest and most expensive of these programs were the Hope Scholarship and the Lifetime Learning Credit, which allowed families of college students to offset their educational costs with tax credits of up to $\$ 1,500$ a year. ${ }^{24}$ These programs primarily benefited middle- and upperincome families, for several reasons. The credits were not refundable, meaning that low-income 
families with no tax liability would not benefit even if they otherwise qualified for the credit. Further, eligible tuition expenses were reduced by any grant aid; as a result, a student who attended the typical two-year college and was poor enough to receive the maximum Pell Grant received no tax credit. Finally, the income cutoffs for eligibility for the subsidies were set so high that less than 10 percent of filing households exceeded them. ${ }^{25}$

In 2009, the Hope Scholarship was expanded and renamed the American Opportunity Tax Credit (AOTC). ${ }^{26}$ The maximum benefit was raised to $\$ 2,500$, with $\$ 1,000$ refundable. Eligible expenses were expanded to include course-related books and supplies. Families were allowed to claim the credit for four years of undergraduate education instead of only two. The maximum benefit under the Lifetime Learning Credit was also raised, to \$2,000. Spending on the AOTC was nearly $\$ 19$ billion in 2010, compared with $\$ 35$ billion for the Pell program. ${ }^{27}$ A key disadvantage of the tax credits is that they are not delivered at the time of enrollment, but up to eighteen months later, when a family files its taxes for the relevant school year. This delay may limit the ability of the tax benefit to influence enrollment or persistence, because low-income individuals who most need the assistance may not be able to wait that long for the money.

Other tax breaks are available for current or former college students. Since 2002, families not claiming one of the education tax credits have been able to deduct up to $\$ 4,000$ in tuition fees from income (even if they do not itemize). Although the benefit officially expired at the end of 2011, it has been retroactively reinstated in the past and may yet be resurrected. ${ }^{28}$ Additionally, up to $\$ 2,500$ in interest on student loans is deductible from taxable income, for households with incomes up to $\$ 75,000$ (single) or $\$ 150,000$ (married). The federal Coverdell Education Savings 
Account and state 529 programs allow annual, after-tax contributions (up to $\$ 2,000$ a year for the Coverdell; the more generous contribution limits and state tax treatment of the 529 vary by state); earnings on the accounts are untaxed if withdrawals are used for educational expenses. ${ }^{29}$ The benefits of these accounts rise sharply with income, because those with the highest marginal tax rates have the most capital income to shelter from taxation. ${ }^{30}$ These additional deductions have little to no value for low-income families, who often take the standard deduction rather than itemize and who face relatively low marginal tax rates.

Finally, while children are generally considered independent for tax purposes after age eighteen, the age limit is extended to twenty-three if the child is enrolled in school. This tax break allows families to save up to several thousand dollars a year for each child enrolled in college because parents can claim a dependent exemption for the student (thus reducing their taxable income), or qualify for the Earned Income Tax Credit (a refundable credit for low-income families). ${ }^{31}$

\section{State Grant Programs}

Traditionally, states have helped to keep college affordable by subsidizing public colleges, which in turn charge lower tuition prices than they would without these subsidies. In recent years, state support for higher education has decreased and shifted from subsidizing institutions toward subsidizing students. In 2010-11, state and local appropriations per full-time-equivalent (FTE) student at public colleges averaged $\$ 7,200$, down 17 percent from $\$ 8,300$ in 1980-81 (figures in

constant 2010 dollars). ${ }^{32}$ Just in the past decade, the share of institutional revenues coming from state and local appropriations has fallen from 56 percent to 42 percent at public, four-year 
colleges. ${ }^{33}$ One potential explanation is that states strapped by costs of prisons, Medicaid, and K12 education see postsecondary education as the one place they can raise prices. ${ }^{34}$

In addition to charging artificially low prices to all students, states also offer scholarships to individual students. States have more than doubled their expenditures on grant aid since 1980 (from $\$ 285$ to $\$ 640$ per FTE). ${ }^{35}$ Still, the increases in state grant aid have not been large enough to make up for the decline in institutional subsidies. Most of these state grants are small-scale programs. But, beginning in the early 1990s, more than a dozen states established broad-based "merit aid" programs, the best-known of which is Georgia's HOPE scholarship. These programs typically award full tuition and fees at state public universities (or in some cases, an equivalent voucher to attend a private school) to residents who maintain a minimum grade point average (GPA) in high school and college. Many require a GPA of 3.0, not a particularly high threshold - in 1999, 40 percent of high school seniors met this standard. ${ }^{36}$ These programs now represent more than a quarter of all state grant aid nationwide and are the primary source of state aid in several states.

\section{How Do Students Apply for Aid?}

To apply for Title IV aid, students must complete the Free Application for Federal Student Aid (FAFSA). This form, which most students now complete online, is also required for many state and institutional aid programs (some institutions also require more detailed additional information). The form requests information about students' own income and savings, their parents' income and savings, their receipt of various other types of governmental assistance, and the amounts of other income and liabilities (such as education tax credits claimed, child support 
paid or received, and other "money received or paid on your behalf") ${ }^{37}$ This information is based upon the preceding tax year (for example, 2011 for students entering college during the 2012-13 academic year), meaning that high school students would not be able to file a FAFSA until at least January of their senior year, or after taxes are filed.

Once the FAFSA is filed, the information is processed under one of eight formulas, depending upon family income, whether a student is classified as dependent or independent, whether the student has children, whether anyone in the household received benefits from another federal means-tested program, and what type of federal income tax form the family is required to use. ${ }^{38}$ The output of this process is an "expected family contribution" (EFC), which is provided to both the students and the schools to which they have applied. While integral to aid eligibility, the EFC can be difficult to interpret: it is described to students as "not the amount of money that your family must provide... [but rather] an index that colleges use to determine how much financial aid you would receive if you were to attend their school. ${ }^{, 39}$ Before 2008, the EFC was the only information on federal aid that students received upon completing the FAFSA; online applicants now also receive an estimate of their Pell eligibility.

Schools use the EFC (and potentially other information from the FAFSA or additional institutional aid application forms) to determine students' eligibility for federal, state, and institutional aid. Students must wait for schools to admit them and present them with details of their aid package. Different schools may offer the same student different amounts of aid. For example, colleges are not required to offer students the maximum Stafford Loans for which they are eligible. 
Complexity, delay, and lack of transparency in the aid process mean that students and their families have little idea how much aid they will receive until after they have applied to college, which students may never do if they think they cannot afford to go. The lack of information about available aid is acute: a recent national survey of 600 Americans aged twenty-six to thirtyfour found that fewer than three in ten individuals without a college degree had any idea what a FAFSA was. ${ }^{40}$ Although the U.S. Department of Education has taken steps to simplify the application process in recent years-by promoting online application (which enables students to skip questions that do not apply to them), for example, and facilitating links with income tax data (which is required for the FAFSA but can be provided directly from the Internal Revenue Service) — the process remains daunting to many students and families. ${ }^{41}$

Federal tax benefits are distributed in an entirely separate process, through the annual filing of income tax returns. Colleges provide documentation directly to the IRS of a student's enrollment and tuition payments. A disadvantage of the education tax benefits is that they are distributed only after costs are incurred; on the other hand, for many families the income tax form is easier to complete than the FAFSA.

\section{Challenges in Evaluating the Effectiveness of Financial Aid}

The theory behind student aid is straightforward: more people will buy a product (college) when its price (tuition) is lower. Price drops, demand increases: that is a lesson taught in any introductory economics course. While Econ 101 clearly predicts that financial aid should increase schooling, the magnitude of the impact is an empirical question. And because aid is 
offered to students on the basis of characteristics that may independently affect college enrollment and completion rates, such as income or academic performance in high school, the effect of the aid the effect of these other factors can be difficult to untangle.

Take the example of Pell Grants, which flow primarily to students from families with income below $\$ 50,000$. Students from such families are less likely to attend college in the first place, for myriad reasons: they disproportionately attended lower-quality high schools, have weaker academic skills, and are less likely to have parents who went to college. ${ }^{42}$ Those who are eligible for a Pell Grant have lower college attendance rates than those who are ineligible, but that does not imply that Pell Grants actually lower college attendance. Those who are eligible for Pell Grants are simply less likely to go to college for reasons other than their Pell eligibility.

Now take the example of state merit-based scholarships. Many states use these grants as a tool to attract high-achieving students. Students eligible for these scholarships are very likely to go to college, given their very strong academic skills. In this case, a comparison of eligible and ineligible students would overstate the effect of aid. Those who are eligible for merit scholarships are likely to go to college for reasons other than their scholarship eligibility.

Researchers typically use statistical methods that are more sophisticated than the paragraphs above would imply. But the same problem plagues the more technical studies: those who are eligible for aid tend to be quite different from those who are not. In theory, researchers can use statistical tools to control for any important differences between aid recipients and nonrecipients, but in practice such research is unlikely. Why? First, complete data on relevant characteristics is 
rarely available. For example, parental wealth affects schooling decisions, both directly and through eligibility for aid, but comprehensive measures of parental (and extended family) wealth are rarely revealed in survey data, especially among adults who have completed their education. Second, and even more fundamentally, students who do receive aid may differ from those who do not on other, unobservable dimensions. As an example, imagine that a sample of first-year Pell Grant recipients could be matched to other first-year students at the same school, with similar age, race, gender, family income, and so on. The question would remain: if these students appear so similar in all of their other characteristics, including family income, which is the primary determinant of Pell Grant eligibility, why did some receive a grant while others did not? Several explanations for this difference may be possible, but most of them will suggest some important unobservable difference between the groups. For example, it may be that the recipients were more committed to a significant period of enrollment, compared with individuals of similar income and ability who did not apply.

The ideal solution is a randomized, controlled trial, in which aid amounts are randomly assigned to a pool of potential college students, who are then followed up after a certain period of time to compare outcomes between those receiving more and those receiving less assistance. The randomized trial is the gold standard of research methods in medicine and is increasingly used in the social sciences. Randomized trials have been used to evaluate the effect of job training programs on employment rates, the effect of smaller classes on test scores, and the effect of Head Start on children's emotional and intellectual development. The Education Sciences Reform Act of 2002 elevated the randomized trial as the preferred method for education, especially for 
research funded by the U.S. Department of Education. Several randomized trials in financial aid are discussed later in this article.

Many policy-relevant questions about aid have yet to be addressed with a randomized trial, however. The next best approach is "quasi-experimental," in which the researcher identifies a source of naturally occurring but idiosyncratic variation in access to aid. When researchers can identify a group that has access to a program and a group that does not for reasons that are, if not explicitly random, at least unrelated to any observable or unobservable differences between the groups, then a comparison of outcomes for these two groups can yield causal estimates of aid effectiveness.

Financial aid eligibility rules have themselves proved to be a rich source of such plausibly random variation. For example, many aid programs have sharp cutoffs for eligibility, with those above specific levels of income or below certain grade point averages being ineligible. Students directly above and below these sharp breaks are likely to be very similar, but the aid that they are offered is quite different. In a regression-discontinuity analysis, researchers compare the schooling decisions of individuals just above and just below these cutoffs and attribute any difference to the causal effect of the difference in aid eligibility. Another quasi-experimental approach exploits sharp changes in aid eligibility. When a program is introduced (or eliminated) for one group but not another, researchers can compare changes in outcomes before and after the policy change across the two groups. Susan Dynarski used this method—-known as a "differencein-difference" approach — to examine the effect of the Social Security student benefit program; we discuss this study below. ${ }^{43}$ 


\section{Lessons from the Research on Financial Aid Effectiveness}

Below we discuss four major lessons that can be taken from the research on financial aid effectiveness, drawing primarily on experimental and quasi-experimental analyses. The rigor of these two approaches does not come without cost. In many cases, running an experiment or identifying a naturally occurring quasi-experiment means narrowing the analysis to a subset of treated and untreated individuals, potentially limiting the ability to generalize the results to other groups. Thus, we also place the findings from the most rigorous studies in the context of the broader nonexperimental literature, where such literature is available.

\section{Lesson 1: Money Matters for College Access}

The first lesson, grounded in more than thirty years of research, is that money matters for college access. As predicted by economic theory, when students know that they will receive a discount, enrollment rates increase. In 1988, Larry Leslie and Paul Brinkman reviewed several dozen nonexperimental studies and concluded that a $\$ 1,000$ decrease in net price was associated with a

3- to 5-percentage-point increase in college attendance. ${ }^{44}$

Susan Dynarski examined the elimination of the Social Security Student Benefit (SSSB) program, using a difference-in-difference analysis. From 1965 to 1982, the Social Security Administration paid for millions of students to go to college. Under the SSSB program, the children of deceased, disabled, or retired Social Security beneficiaries received monthly payments while in college. At the program's peak, 12 percent of young full-time college students were receiving these benefits. In 1981, Congress voted to eliminate the program. Except for the 
introduction of the Pell Grant program in the early 1970s, and the various GI Bills, elimination of this program is the largest and sharpest change in grant aid for college that has ever occurred in the United States. Dynarksi found that college attendance among the affected group fell by more than a third after the grant program ended, suggesting that the availability of grant aid does in fact increase college enrollment rates above what they would be otherwise.

Several quasi-experimental studies of large state merit aid programs have also found significant positive impacts on enrollment, as did a regression-discontinuity study of the Tuition Assistance Program in the District of Columbia and two separate studies of the mid-century G.I. Bills. Taken together, the quasi-experimental evidence suggests that an additional $\$ 1,000$ of grant aid may increase college enrollment by 4 percentage points. ${ }^{45}$

Grant assistance affects not only whether students attend college but also where they choose to go. For students applying to an elite East Coast institution who also applied for financial aid, an additional 10 percent in grant aid increased the probability of matriculation by 8.6 percent. ${ }^{46}$ This estimate was obtained using a regression-discontinuity design, in which students were ranked according to the strength of their application, and the matriculation rate of students just below discrete aid-eligibility cutoffs was compared with the rate of those just above the cutoff.

Like grant aid, federal tax benefits provide money for college that never needs to be repaid. Evidence regarding the enrollment effects of the tax benefits is limited to just two studies. An early study using a difference-in-difference approach—comparing financially eligible and ineligible families before and after the introduction of the Hope and Lifetime Learning tax 
credits — found no evidence that the benefits influenced likelihood of enrollment. ${ }^{47}$ A more recent study used a similar difference-in-difference strategy, but included the new American Opportunity Tax Credit in its analysis and also took advantage of more accurate data on income eligibility. ${ }^{48}$ This study found effects of roughly the same magnitude as has been found for grant assistance: the probability of college enrollment rose by 3 percentage points for every $\$ 1,000$ of tax-based aid. It is possible that earlier analysis simply could not discern a true effect because some families were incorrectly classified as eligible or ineligible in the data, watering down the estimated difference between groups. Or it is possible that the new refundable American Opportunity Tax Credit has different effects from its predecessors, because it extends benefits to families with zero or low tax liability.

Until recently much of the financial aid literature focused on college entry, rather than outcomes after enrollment. Several recent studies suggest that financial aid can also improve persistence and completion. ${ }^{49}$ These studies, however, generally examine grant programs with specific academic achievement requirements for scholarship renewal. The results of these academic incentive grants do not necessarily generalize to grant programs with no strings attached, a caveat discussed under Lesson 3.

\section{Lesson 2: Program Complexity Undermines Aid Effectiveness}

While we conclude that aid matters for college enrollment, that does not imply that all aid programs are equally effective. For example, the programs discussed above that have clearly demonstrated positive impacts on college enrollment tend to have simple, easy-to-understand eligibility rules and application procedures. The eligibility and application rules for Pell 
Grants - the nation's largest grant program — are comparatively complex, requiring students to submit to the lengthy and burdensome FAFSA process for determining their eligibility.

A recent experimental study by Eric Bettinger and colleagues provides dramatic evidence that the complexity of the financial aid application process can itself become a significant barrier to college access. ${ }^{50}$ In the experiment, low-income families who visited a tax-preparation center were randomly assigned to one of three groups: a "full treatment" group that received both personalized information about eligibility for financial aid as well as personal assistance with completing and submitting the FAFSA; an "information-only" group that received personalized information about financial aid eligibility but no application assistance; and a control group that received a brochure with general information about college costs, financial aid, and the value of going to college. The full treatment, which took less than ten minutes and cost less than $\$ 100$ per participant, increased immediate college entry rates by 8 percentage points ( 24 percent) for high school seniors and 1.5 percentage points (16 percent) among independent participants with no previous college experience. After three years, participants in the full-treatment group had accumulated significantly more time in college than the control group. They also were much more likely to have received a Pell Grant.

This experimental evidence, which demonstrates the importance of program design and delivery, may help explain why studies have found less conclusive evidence regarding the enrollment impact of Pell Grants than for aid programs with simpler eligibility and application procedures. The broadest quasi-experimental study of Pell Grants used a difference-in-difference approach to compare trends in college enrollment before and after increases in Pell Grant funding, between 
students who became eligible for increased funding and those who remained ineligible throughout the period. Consistent with previous nonexperimental findings, this study found no detectable effect of the introduction of Pell Grants on college enrollments for eligible (lowincome) populations. ${ }^{51}$

Other studies have found evidence of Pell impacts for specific subsets of the population: one study found that Pell Grants increased enrollment of older "nontraditional" students, while a study by Bettinger, described in the next section, found weak suggestive evidence that the grants contributed to student persistence, at least among students who had already enrolled in college. ${ }^{52}$ Both findings are consistent with a story in which information and experience with bureaucracy is important: older individuals may have learned about the Pell program over time, and continuing students may learn about the program once they enroll in school. Those who have recently graduated from high school but not yet enrolled may be the least informed and least equipped to figure out the process.

This limited evidence on the impact of Pell Grants is not definitive (the US Department of Education recently initiated a randomized trial to study the effect of further expansions of the Pell Grant, which may help to resolve this uncertainty). But at a minimum, the FAFSA experiment by Eric Bettinger and colleagues has only heightened existing concerns that complexity and confusion surrounding the Pell eligibility and application process may be obscuring its benefits and dampening its impact among the individuals who need it most - those who are on the fence about college for financial reasons. ${ }^{53}$ 
Lesson 3: Academic Incentives Appear to Augment Aid Effectiveness, Particularly after

\section{Enrollment}

A third emerging lesson from the literature is that achievement incentives appear to increase effectiveness, particularly when the focus is on improving college performance and completion (as opposed to simply access). Two randomized experiments have examined the results of linking financial aid to specific GPA or credit accumulation requirements. One study by MDRC, examining a sample of low-income, primarily minority, female enrollees at two community colleges in Louisiana, found that performance-based scholarships increased GPAs and persistence.$^{54}$ On the basis of these findings, MDRC initiated replication studies examining variations of this intervention in six other states; early indicators appear to reinforce the findings of the initial study ${ }^{55}$ An experiment at a large college in Canada found that a performance-based scholarship did in fact increase GPAs, though only for females who received academic support services in addition to the financial incentive. ${ }^{56}$ While the lack of significant impacts for the full sample may be surprising, again there is suggestive evidence that program complexity may undermine effectiveness: a subsequent experiment with cash incentives at the same Canadian institution again found no effects overall, but found some significant positive effects only for those students receiving grades above the minimum threshold established for the incentive, with larger effects on grade outcomes for students who could correctly describe the program's rules. ${ }^{57}$

To the extent that performance-based scholarships encourage students to devote more time and energy to their studies, an important question is whether the student may be driven purely by the relaxation of financial constraints, rather than by the performance incentives per se. A quasiexperimental study by Judith Scott-Clayton examines this question, in the context of West 
Virginia's PROMISE scholarship, which at the time provided free tuition and fees for up to four years to academically eligible students as long as they maintained a minimum GPA and course load in college. ${ }^{58}$ The scholarship increased five-year graduation rates by 4 percentage points and on-time graduation rates by nearly 7 percentage points. Moreover, the achievement incentives were an important mechanism driving these increases. The scholarship increased GPAs and credits completed in the first three years of college, but in the fourth and final year of the scholarship_-while students are still receiving the money but no longer face the achievement incentives — the program's effect disappeared.

In contrast, several studies of pure grants (with weak or no achievement incentives) have found less conclusive evidence of positive effects on persistence and graduation rates. Two quasiexperimental studies found suggestive but inconclusive evidence that pure grant aid improves college persistence and completion. ${ }^{59}$ In contrast, a regression-discontinuity study of the Gates Millennium Scholarship (GMS) found no evidence that the grants increased college retention or credit accumulation for its highly qualified, low-income minority participants (although it did reduce student employment and student loan debt). ${ }^{60}$

The most rigorous and broadly relevant evidence on the post-enrollment effects of grant aid comes from a randomized evaluation of the Wisconsin Scholars Grant, a privately run scholarship program that provided $\$ 3,500$ grants to Pell-eligible students already enrolled at public universities in Wisconsin. The study found no effects on persistence, grade point averages, or credit accumulation after three years for the full sample. ${ }^{61}$ However, for a subset of 
students entering college with a high risk of dropout (based on high school achievement and other background characteristics), the effects seemed to be more positive.

Academic incentives may improve not only performance after college entry but college preparation and initial enrollment as well. For example, a study of the introduction of Tennessee's state merit aid program, which provided large college scholarships to students with minimum high school GPA and SAT/ACT test scores, found that the scholarship significantly improved high school achievement as measured by ACT test scores (the increases in test scores were too large to be explained simply by increases in retesting). ${ }^{62}$ A similar study of a program in Texas that paid eleventh- and twelfth-grade students and teachers for earning passing scores on Advanced Placement (AP) exams found that the policy not only improved AP exam scores but increased college enrollment rates as well as college academic performance even for those students who would have gone to college anyway. ${ }^{63}$

\section{Lesson 4: Evidence on the Effect of Loans Is Limited but Suggests Design Is Important}

A fourth lesson is that even though loans are unpopular, they are a critical element in college financing, and their design might be significantly improved to minimize students' repayment risks and better communicate both risks and protections upfront. Very little rigorous research has examined how the availability of student loans affects college enrollment, performance, or completion. Susan Dynarski found suggestive, but ultimately inconclusive evidence that student loan expansions in the United States in the early 1990s led to increased college attendance. ${ }^{64}$ Donald Heller reviewed the nonexperimental literature on whether loans increase college access and concluded that the findings "can at best be described as mixed." ${ }^{, 65}$ In part, this mixed picture 
may reflect inconsistencies in some researchers' choice of the counterfactual: the studies may be comparing \$1 of loans with \$1 of grants, \$1 of work-study, or no aid at all. Based on the nonexperimental evidence, Heller concluded that college enrollments are not as sensitive to loans as to grants. This is unsurprising given that loans are not worth as much to students.

Nonetheless, since they also cost the government only a few cents on the dollar to provide, it remains an open question whether loans provide bigger, smaller, or the same "bang for the buck" as grant aid does. ${ }^{66}$

More rigorous evidence from a dramatic policy change at one selective northeastern university suggests that students' career choices, if not their enrollment decisions, are influenced by levels of student debt. Jesse Rothstein and Cecilia Rouse examined the consequences of this institution's decision to replace loans in students' financial aid packages with increased institutional grant aid. ${ }^{67}$ In two stages, the university in 1998 eliminated student loans for incoming students from low-income families and then eliminated loans for all students receiving aid in 2001. Students in cohorts that entered after the policy was fully implemented not only graduated with about $\$ 11,000$ less in debt than cohorts that entered before the policy change but also were significantly more likely to take jobs in nonprofit and public service sectors.

Debt aversion may be one important explanation for why loans do not appear to affect access as much as grants do: some students simply dislike being in debt, even when that debt enables an investment with high average returns. An experiment analyzed by Erica Field found strong evidence that students (in this case, students admitted to law school) are debt averse. ${ }^{68}$ Admitted students at one school were randomly assigned to receive either a public service scholarship that 
would convert to a loan if students did not pursue public service after graduation, or a loan that would be forgiven if students decided to pursue public service after graduation. The two treatments were financially equivalent, yet framing the program as a "loan that would be forgiven if you pursue public service" was much less effective in inducing students to public service than a "grant that will convert to a loan if you do not pursue public service." Like the FAFSA simplification study, Field's findings provide further evidence that the details of program design and marketing can be critical.

Given the widespread reliance on student loans, a more interesting question than whether they increase college enrollment and completion at all is whether some types of loans are more effective than others. Are there ways to make loans more attractive and less risky for students, without drastically increasing costs? For example, the cost of a loan program is greatly affected by the interest rate that is charged and whether interest accrues while students are still enrolled in school. Yet evidence from other contexts indicates that individuals do not give such details as much weight as they should when making savings and borrowing decisions. ${ }^{69}$ Similarly, with income-contingent repayment schemes, it is unclear whether students making decisions about borrowing are even aware of how their eventual payments will be calculated. If loan schemes cannot be made more comprehensible to students, any subsidies incorporated into loan programs to make them more appealing to low-income students may be ineffectual. A student's decision to enroll and persist may be more influenced by an aid package that includes an upfront grant and an unsubsidized loan, rather than a package of equal cost to the government that includes only subsidized loans. 


\section{Conclusion}

The major shifts in the financial aid landscape documented in this paper have three critical implications for aid policy. First, student aid is no longer just for poor students. Forty years ago, student aid consisted almost solely of federal grants for low-income students. Today, colleges and states, as well as the federal government, provide grants, tax benefits, and loans to families with incomes well up the income distribution. ${ }^{70}$ In fact, the majority of students now receive financial aid of one kind or another: two-thirds of full-time college students get some form of grant aid, and many of the remainder receive federal tax credits and other forms of assistance. The aggregate amount of student aid distributed - including all forms of aid at the federal, state, and institutional level—added up to nearly $\$ 13,000$ a student in 2010-11. The volume of aid distributed and numbers of students affected make it more critical than ever to understand whether and how aid affects college enrollment, performance, and completion.

Second, the "sticker price" of college now diverges substantially from the net price most families face. Sticker prices have climbed steadily for decades. But net prices in all sectors were actually lower in 2009-10 than they were in 2005-06. The net price of a private four-year college declined by 2 percent between 2005 and 2009, and the net price for a public four-year college declined by 13 percent over this period. For public two-year institutions, average net prices dropped to negative $\$ 810$, meaning the average student received more in grant aid than he or she was charged in tuition and fees. ${ }^{71}$ The difference between sticker prices and net prices is even larger for low-income students, who qualify for the Pell Grant, which has grown increasingly generous in recent years. This divergence implies that individual students will find it harder than ever to estimate how much going to college will cost them. 
Third, the increasing scope and diversity of financial aid programs implies increased complexity — both for students trying to estimate their college costs and for policy makers trying to ensure coherence across programs. The proliferation of programs, each well-intentioned, has created a system that makes it difficult for families - especially "first-generation" families in which neither parent has attended college — to know just how affordable college can be. Calculating the net price of college for a given family requires understanding their finances as well as the rules of the Pell Grant, student loans, the tuition tax credits, state grant programs, and aid offered by individual colleges. Evidence suggests that students are quite poor at estimating net prices. $^{72}$ A symptom of the general confusion is that some aid goes unclaimed: the Government Accountability Office recently calculated that 14 percent of families eligible for an education tax benefit failed to claim it. ${ }^{73}$ Forty percent of filers who used the tuition tax deduction would have been better off claiming one of the tax credits instead.

The complexity of the student aid landscape can lead to unexpected interactions between programs. For example, Susan Dynarski found that, for families on the margin of getting more financial aid, putting money in a tax-advantaged Coverdell Savings Account led to substantial decreases in Title IV aid eligibility. In other words, the Title IV rules not only undid the tax incentive for saving but actually left a family worse off than if it had not saved at all. This collision between tax and aid policy was corrected with subsequent legislation, but there will almost certainly be more such collisions given the proliferation of aid and tax programs. 
Another example of unintended interactions regards the relationship between federal aid and colleges' own tuition pricing and financial aid decisions. Some policy makers, most notably former U.S. Secretary of Education William Bennett, have raised the concern that even if financial aid lowers prices for some students, it might enable institutions to raise tuition costs overall. Some evidence supports the so-called "Bennett Hypothesis" in the for-profit sector: Stephanie Cellini and Claudia Goldin find that proprietary schools that are eligible to receive federal Title IV aid (via eligible students who enroll) charge significantly more than similar institutions that must rely on students who can pay full price. ${ }^{74}$ But other research finds little evidence of these effects at the public institutions attended by the majority of students. ${ }^{75}$ More subtly, recent quasi-experimental work by Lesley Turner comparing financial aid packages for students just above and below Pell Grant eligibility thresholds finds that selective nonprofit institutions claw back up to two-thirds of Pell Grant awards through reductions in institutional grant aid. However, at the public institutions most Pell recipients attend, the claw-back rate is near zero. $^{76}$

Researchers have learned an enormous amount about the effect of aid on student behavior in recent years, as the quantity and quality of research on this topic has exploded. Aid can matter, with simple, well-designed programs producing large increases in college attendance and completion. Evidence shows that the complexity of eligibility and application procedures can undermine aid effectiveness. A recent randomized trial showed that a massive simplification of the federal aid application process produced substantial increases in college attendance, further bolstering the conclusion that design matters. It also appears that pairing grants with academic requirements can bolster the impact of financial aid on college performance and completion. 
Both experimental and quasi-experimental studies have shown that dollars with strings attached produce larger effects than dollars alone.

In contrast, disappointingly little evidence is available on the effects of one method that students increasingly use to pay for college: loans. Loans are likely to remain a key component of student aid packages, yet almost no evidence exists about their effects on college enrollment and completion. Finally, as both the types of aid and the types of aid recipients continue to expand and diversify, more research is likely to focus on the importance of program design and delivery, whether there are unanticipated interactions between programs, and to what extent program effects vary across different types of students.

As state and federal budgets face increasing pressures and politicians look for ways to control spending, financial aid programs will be vulnerable to cutbacks if evidence is lacking on their effectiveness, and even those programs with documented positive effects may be asked to do more with less. Fortunately, more may be known about the effects of financial aid than about any other interventions aimed at increasing postsecondary attainment. No longer is it necessary to ask the question, "Does aid work?"-for the research definitively shows that it can. But the evidence also suggests that some programs work better than others, and because of the magnitude of government investment as well as the numbers of individuals affected by student aid, the stakes have never been higher for understanding what aid programs work best and why. 


\section{Trends in Undergraduate Enrollment and Aid Per Student, 1971-2010}

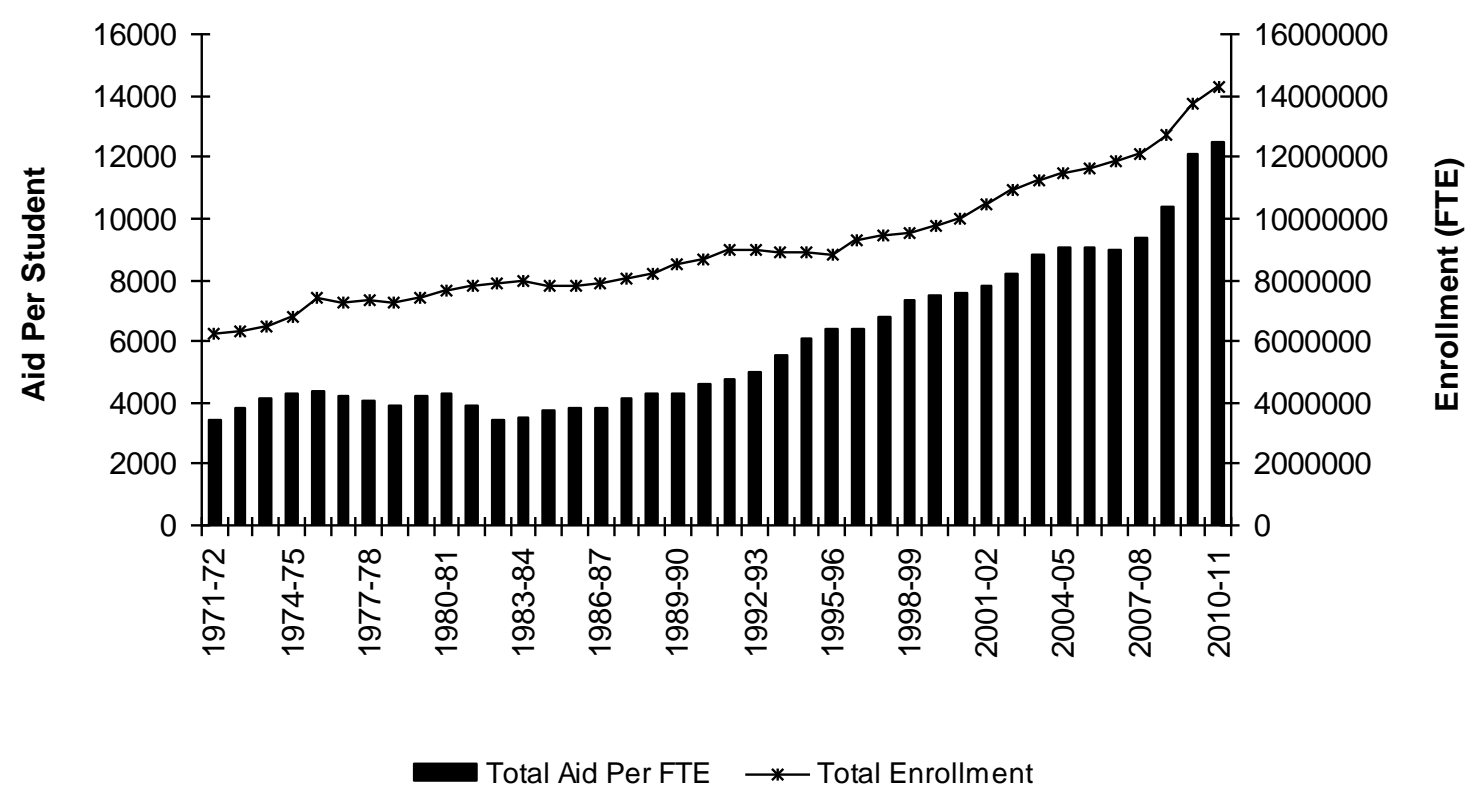

Source: College Board, Trends in Student Aid 2011, Table 3A (1990-91 through 2010-11), and authors' calculations from Table 3 (1971-72 through 1989-90).

Notes: Enrollment measured in full-time equivalent (FTE) undergraduates. Aid is per undergraduate FTE student (including nonrecipients) and includes undergraduate grant aid from all sources, loans from all sources, federal work-study, and federal tax benefits. Aid is measured in 2010 constant dollars. 
Figure 2

Number of Pell Recipients and Average Award, 1976-77-2010-11

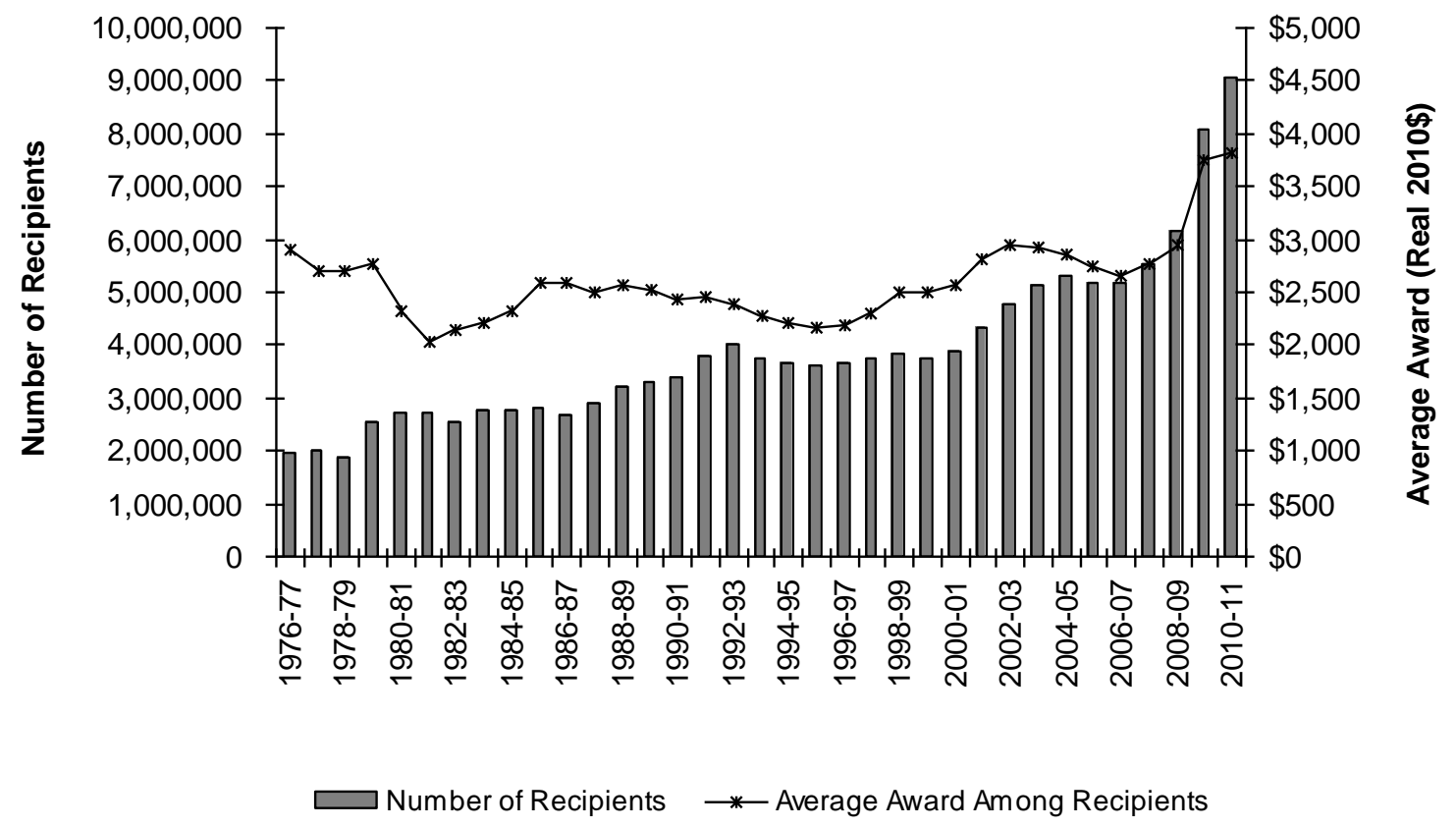

Source: College Board (2011), Trends in Student Aid, Figure 13A, and U.S. Department of Education (2011), Pell End of Year Report, 2009-10.

Notes: Average awards are measured in 2010 constant dollars, and represent the average among Pell recipients. 


\section{Table 1}

Support for Undergraduate Students by Source, 1990-91 to 2010-11

\begin{tabular}{|l|r|r|r|}
\hline & \multicolumn{3}{|c|}{ Year } \\
\cline { 2 - 4 } & $1990-91$ & $2000-01$ & $2010-11$ \\
\hline Federal Programs & & & \\
\hline Total Federal Grants & $\$ 10.9$ & $\$ 13.5$ & $\$ 47.8$ \\
\hline$\quad$ Pell Grants & $\$ 8.3$ & $\$ 10.0$ & $\$ 34.8$ \\
\hline Veterans & $\$ 1.1$ & $\$ 1.9$ & $\$ 10.0$ \\
\hline Other Grants & $\$ 1.5$ & $\$ 1.6$ & $\$ 3.1$ \\
\hline Total Federal Loans & $\$ 14.0$ & $\$ 29.9$ & $\$ 70.0$ \\
\hline$\quad$ Subsidized Stafford & $\$ 10.3$ & $\$ 14.4$ & $\$ 28.4$ \\
\hline$\quad$ Unsubsidized Stafford & $\$ 0.0$ & $\$ 9.7$ & $\$ 30.3$ \\
\hline$\quad$ PLUS (Parent) Loans & $\$ 1.4$ & $\$ 4.7$ & $\$ 10.4$ \\
\hline Other Federal Loans & $\$ 2.3$ & $\$ 1.2$ & $\$ 0.8$ \\
\hline Federal Work-Study & $\$ 1.2$ & $\$ 1.1$ & $\$ 1.0$ \\
\hline Education Tax Credits & $\$ 0.0$ & $\$ 4.9$ & $\$ 18.8$ \\
\hline State Grant Programs & $\$ 3.0$ & $\$ 5.9$ & $\$ 9.1$ \\
\hline Grants From Colleges & $\$ 8.1$ & $\$ 15.3$ & $\$ 29.7$ \\
\hline Private \& Employer Grants & $\$ 2.6$ & $\$ 5.1$ & $\$ 6.6$ \\
\hline Nonfederal Loans & $\$ 0.0$ & $\$ 4.4$ & $\$ 6.5$ \\
\hline Total Support for Undergraduate Students & $\$ 39.8$ & $\$ 80.1$ & $\$ 189.6$ \\
\hline Total non-loan aid & $\$ 25.7$ & $\$ 45.7$ & $\$ 113.1$ \\
\hline
\end{tabular}

Source: Education Tax Credit data from Internal Revenue Service (2000, 2005, 2010), Statistics of Income, Table 3.3. All other components from College Board (2011), Trends in Student Aid, Table $1 \mathrm{~A}$.

Notes: All values in 2010 constant dollars. Components may not sum to totals because of rounding. Federal Loan dollars reflect disbursements beginning 199596. Prior to 1995-96 the data reflect gross loan commitments. Figures for 2010-11 are preliminary estimates. 


\section{Notes}

1. Lyndon Baines Johnson, "Remarks at Southwest Texas State College Upon Signing the Higher Education Act of 1965," November 8, 1965. Archived online by Gerhard Peters and John T. Woolley, The American Presidency Project (www.presidency.ucsb.edu/ws/?pid=27356).

2. Sandy Baum and Kathleen Payea, Trends in Student Aid 2011 (New York: The College Board, 2011), tables 3 and 3A. Before 1990, the original College Board data combined data on both graduate and undergraduate aid and enrollment. For 1971-72 through 1989-90, we adjusted the aggregate enrollment estimates downward by 13 percent and the average aid estimates downward by 11 percent (based on the undergraduate-to-total ratios, which have been relatively stable over time, from later years in which both series are available) to make them comparable with the undergraduate-only data for subsequent years.

3. Full-time equivalent statistics count two half-time students the same as one full-time student; the number of individual students enrolled surpassed 20 million by 2009 .

4. Before 1980, the department was known as the Department of Health, Education, and Welfare. 5. Sandy Baum and Jennifer Ma, Trends in College Pricing 2011 (New York: The College Board 2011).

6. Ibid., table 7.

7. Laura J. Horn, Xianglei Chen, and Chris Chapman, Getting Ready to Pay for College: What Students and Their Parents Know about the Cost of College Tuition and What They Are Doing to Find Out (Washington: National Center for Education Statistics, 2003); Stanley Ikenberry and Terry Hartle, Too Little Knowledge Is a Dangerous Thing: What the Public Thinks about Paying for College (Washington: American Council on Education, 1998). Also see the review by Judith 
Scott-Clayton, "Information Constraints and Financial Aid Policy,” Working Paper 17811

(Cambridge, Mass: National Bureau of Economic Research, 2012).

8. Lawrence E. Gladieux and Arthur M. Hauptman, The College Aid Quandary: Access, Quality, and the Federal Role (Washington: Brookings Institution Press, 1995), p. 15.

9. Numbers of Pell Grant recipients over time come from Baum and Payea, Trends in Student

Aid 2011 (see note 2), table 8. Enrollments over time come from National Center for Education Statistics, Digest of Education Statistics 2009 (U.S. Department of Education, 2010), table 197.

10. Baum and Payea, Trends in Student Aid 2011 (see note 2), table 8.

11. Sandy Baum, Charles Kurose, and Michael McPherson, "An Overview of American Higher Education," Future of Children 23, no. 1 (Spring 2013).

12. Bureau of the Census, "Regions-All Races by Median and Mean Income 1975-2010" (www.census.gov/hhes/www/income/data/historical/household/2010/H06AR_2010.xls), table H6.

13. U. S. Department of Education, "Federal Pell Grant Program Data Books: 2000-01-2009-10" (dependent students) (www2.ed.gov/finaid/prof/resources/data/pell-historical/hist-4.html).

14. Baum and Payea, Trends in Student Aid 2011 (see note 2), figures 13A and 13C.

15. Ibid.

16. FinAid.org, "History of Student Financial Aid" (www.finaid.org/educators/history.phtml).

17. Baum and Ma, Trends in College Pricing 2011 (see note 4), figure 3.

18. See, for example, Antony Davies and James R. Harrison, "Why the Education Bubble Will Be Worse than the Housing Bubble," USNews.com, June 12, 2012. 
19. Rohit Chopra, “Too Big to Fail: Student Debt Hits a Trillion” (Washington: Consumer Financial Protection Bureau, March 21, 2012 (www.consumerfinance.gov/blog/too-big-to-failstudent-debt-hits-a-trillion/).

20. Note that cumulative debt figures cited in the press as "record highs" typically fail to adjust previous years' figures for inflation.

21. Data for 2000 come from National Center for Education Statistics, Debt Burden: A Comparison of 1992-93 and 1999-00 Bachelor's Degree Recipients a Year after Graduating (U.S. Department of Education, 2005). Data for 2009 come from National Center for Education Statistics, QuickStats: BPS:2009 Beginning Postsecondary Students Database (http://nces.ed.gov/datalab/quickstats/).

22. Authors' computations using National Center for Education Statistics, QuickStats: BPS:2001 Beginning Postsecondary Students Database and BPS:2009 Beginning Postsecondary Students Database (http://nces.ed.gov/datalab/quickstats/).

23. National Center for Education Statistics, QuickStats: BPS:2009 Beginning Postsecondary Students Database (http://nces.ed.gov/datalab/quickstats/).

24. Families may claim an American Opportunity Tax Credit for each eligible student in the household, while only one Lifetime Learning Credit may be claimed per household. Only one credit can be claimed per student. See Internal Revenue Service, Tax Benefits for Education: For Use in Preparing 2011 Returns, Publication 970 (Department of the Treasury, 2001). 25. Susan M. Dynarski, "Hope for Whom? Financial Aid for the Middle Class and Its Impact on College Attendance." National Tax Journal 53, no. 3 (2000): 629-61.

26. The American Opportunity Tax Credit modifies the Hope and Lifetime Learning Credits through December 2012, when the modifications were scheduled to expire. 
27. Margot Crandall-Hollick, “The American Opportunity Tax Credit: Overview, Analysis, and Policy Options," Congressional Research Service Report R42561 (Government Printing Office, 2012).

28. The benefit was originally set to expire in 2005, but in 2006 it was extended to cover 2006 and 2007; in 2008, it was extended to cover 2008 and 2009; and in 2010, it was extended to cover 2010 and 2011. For 2011, the income limit for this benefit was $\$ 80,000$ for single filers or $\$ 160,000$ for joint returns.

29. State cumulative contribution limits range from $\$ 146,000$ to $\$ 305,000$; a typical state allows an annual contribution of $\$ 10,000$ for married filers. See FinAid.org, "FinAid: Saving for College: Section 529 Plans” (www.finaid.org/savings/529plans.phtml\#Contributions); FinAid.org, "History of Student Financial Aid" (www.finaid.org/educators/history.phtml). 30. Susan M. Dynarski, "Who Benefits from the College Saving Incentives? Income, Educational Expectations and the Value of the 529 and Coverdell." National Tax Journal 57, no. 2 (2004): 359-83.

31. Government Accountability Office, "Improved Tax Information Could Help Families Pay for College," GAO-12-560 (Government Printing Office, 2012).

32. College Board, Trends in College Pricing, 2011, figure 10b (see note 5).

33. College Board, Trends in College Pricing, 2011, figure 12a (see note 5).

34. Thomas J. Kane and Peter R. Orszag, "Funding Restrictions at Public Universities: Effects and Policy Implications,” Working Paper (Washington: Brookings Institution, 2003).

35. Need-based state grants per full-time-equivalent undergraduate student grew from \$211 in 1969-70 to \$464 in 2009-10 (constant 2010 dollars), while merit-based grants per FTE 
undergraduate grew from $\$ 0$ in 1969-70 to \$176 in 2009-10. Baum and Payea, Trends in Student Aid 2011, figure 15A (see note 2).

36. Susan M. Dynarski, "The New Merit Aid," in College Choices: The Economics of Where to Go, When to Go, and How to Pay for It, edited by Caroline M. Hoxby (University of Chicago Press and the National Bureau of Economic Research, 2004), pp. 63-100.

37. See the 2012-13 FAFSA On The Web Worksheet http://www.fafsa.ed.gov/fotw1213/pdf/fafsaws13c.pdf).

38. The choice of formula and the formulas themselves are not computed by the student for obvious reasons, nor are they made accessible to students and their families. But enterprising individuals could find copies of the thirty-six-page formula guide online (http://studentaid.ed.gov/sites/default/files/2012-13-efc-forumula.pdf)

39. Edicsweb.ed.gov, "2012-2013 Student Aid Report”

(edicsweb.ed.gov/edics_files_web/04703/Att_2012-2013\%20Student\%20Aid\%20Report.pdf). Emphasis in original.

40. Jean Johnson, Jon Rochkind, and Amber Ott, One Degree of Separation: How Young Americans Who Don't Finish College See Their Chances for Success (San Francisco: Public Agenda, 2011).

41. Susan M. Dynarski and Judith Scott-Clayton, "The Cost of Complexity in Federal Student Aid: Lessons from Optimal Tax Theory and Behavioral Economics," National Tax Journal 59, no. 2 (2006): 319-56; Susan M. Dynarski and Mark Wiederspan, "Student Aid Simplification: Looking Back and Looking Ahead," National Tax Journal 65, no. 1 (2012): 211-34. 
42. Martha Bailey and Susan M. Dynarski, "Inequality in Postsecondary Attainment," in Whither Opportunity: Rising Inequality, Schools, and Children's Life Chances, edited by Greg Duncan and Richard Murnane (New York: Russell Sage Foundation, 2011), pp. 117-32.

43. Susan M. Dynarski, “Does Aid Matter? Measuring the Effect of Student Aid on College Attendance and Completion," American Economic Review 93, no. 1 (2003): 278-88.

44. Larry Leslie and Paul Brinkman, The Economic Value of Higher Education (New York: Macmillan, 1988).

45. For a detailed review, see David Deming and Susan M. Dynarski, "Into College, Out of Poverty? Policies to Increase the Postsecondary Attainment of the Poor,” Working Paper 15387 (Cambridge, Mass: National Bureau of Economic Research, 2009). The following studies find enrollment effects ranging from 3 to 6 percentage points per $\$ 1,000$ of aid: Neil Seftor and Sarah Turner, "Back to School: Federal Student Aid Policy and Adult College Enrollment," Journal of Human Resources 37, no. 2 (2002): 336-52; Thomas J. Kane, “A Quasi-Experimental Estimate of the Impact of Financial Aid on College-Going," Working Paper 9703 (Cambridge, Mass.: National Bureau of Economic Research, 2003); Thomas J. Kane, "Evaluating the Impact of the D.C. Tuition Assistance Grant Program," Journal of Human Resources 42, no. 3 (2007): 555-82; Katharine Abraham and Melissa Clark, "Financial Aid and Students' College Decisions: Evidence from the District of Columbia Tuition Assistance Grant Program” Journal of Human Resources (Summer 2006): 578-610; Dynarski, “Hope for Whom? (see note (23); Dynarski, “The New Merit Aid” (see note 34); Christopher Cornwell, David Mustard, and Deepa Sridhar, “The Enrollment Effects of Merit-Based Financial Aid: Evidence from Georgia’s HOPE Scholarship," Journal of Labor Economics 24 (2006): 761-86; Marcus Stanley, “College Education and the Mid-Century G.I. Bills," Quarterly Journal of Economics 118, no. 2 (2003): 
671-708; John Bound and Sarah Turner, "Going to War and Going to College: Did World War II and the G.I. Bill Increase Educational Attainment for Returning Veterans?” Journal of Labor Economics 20, no. 4 (2002): 784-815.

46. Wilbert van der Klaauw, "Estimating the Effect of Financial Aid Offers on College Enrollment: A Regression-Discontinuity Approach.” International Economic Review 43, no. 4 (2002): 1249-87.

47. Bridget T. Long, "The Impact of Federal Tax Credits for Higher Education Expenses," in College Choices: The Economics of Where To Go, When To Go, and How To Pay for It, edited by Caroline M. Hoxby (Chicago: University of Chicago Press, 2004), pp. 101-68.

48. Nicholas Turner, "The Effect of Tax-Based Federal Student Aid on College Enrollment," National Tax Journal 64, no. 3 (2011): 839-62.

49. Susan M. Dynarski, "Building the Stock of College-Educated Labor," Journal of Human Resources 43, no. 3 (2008): 576-610; Lashawn Richburg-Hayes and others, Rewarding Persistence: Effects of a Performance-Based Scholarship Program for Low-Income Parents, (New York: MDRC, 2009); Reshma Patel and Lashawn Richburg-Hayes, Performance-Based Scholarships: Emerging Findings from a National Demonstration (New York: MDRC, 2012). Judith Scott-Clayton, “On Money and Motivation: A Quasi-Experimental Analysis of Financial Incentives for College Achievement," Journal of Human Resources 46, no. 3 (2011): 614-46. 50. Eric Bettinger and others, "The Role of Application Assistance and Information in College Decisions: Results from the H\&R Block FAFSA Experiment," Quarterly Journal of Economics (forthcoming, 2012).

51. Thomas J. Kane, "Lessons From the Largest School Voucher Program Ever: Two Decades of Experience with Pell Grants," in Who Chooses? Who Loses? Culture, Institutions and the 
Unequal Effects of School Choice, edited by Bruce Fuller, Richard F. Elmore, and Gary Orfield (Teachers College Press, 1996); W. Lee Hansen, “The Impact of Student Financial Aid on Access," in The Crisis In Higher Education, edited by Joseph Froomkin (New York: Academy of Political Science, 1983), pp. 84-96.

52. Seftor and Turner, "Back to School (see note 45); Eric Bettinger, "How Financial Aid Affects Persistence," in College Choices: The Economics of Where To Go, When To Go, and How To Pay for It, edited by Caroline M. Hoxby (University of Chicago Press and the National Bureau of Economic Research, 2004), pp. 207-38.

53. Dynarski and Scott-Clayton, "The Cost of Complexity in Federal Student Aid” (see note 41). 54. Richburg-Hayes and others, Rewarding Persistence (see note 49).

55. Patel and Richburg-Hayes, Performance-Based Scholarships (see note 49).

56. Joshua D. Angrist, Daniel Lang, and Philip Oreopoulos, "Incentives and Services for College Achievement: Evidence from a Randomized Trial," American Economic Journal: Applied Economics 1, no. 1 (2009): 136-63.

57. Joshua Angrist, Philip Oreopoulos, and Tyler Williams, "When Opportunity Knocks, Who Answers? New Evidence on College Achievement Awards," Working Paper 16643 (Cambridge, Mass.: National Bureau of Economic Research, 2010). Even for the sample of students who understood program rules, there was no impact on average GPA, but there were significant impacts on the number of courses in which students received a grade above 70 (out of 100). 58. Scott-Clayton, "On Money and Motivation (see note 49). Since the time of the study, West Virginia has capped the value of the scholarship so that it no longer guarantees free tuition, but provides a fixed-dollar award. 
59. A study by Eric Bettinger used discontinuities in the Pell Grant formula to estimate the effects of Pell Grant size on college persistence (conditional on enrollment). See Bettinger, "How Financial Aid Affects Persistence" (see note 52). Similarly, Dynarski's study of the SSSB program, described above, finds positive, but statistically insignificant effects on completed years of schooling. See Dynarski, “Does Aid Matter?” (see note 43).

60. Stephen L. DesJardins and Brian P. McCall, "The Impact of the Gates Millennium Scholars Program on Selected Outcomes of Low-Income Minority Students: A Regression Discontinuity Analysis" (University of Michigan, 2008). Also see Stephen L. DesJardins and others, “A QuasiExperimental Investigation of How the Gates Millennium Scholars Program Is Related to College Students' Time Use and Activities," Educational Evaluation and Policy Analysis 32, no. 4 (2010): 456-75.

61. Sara Goldrick-Rab and others, "Conditional Cash Transfers and College Persistence: Evidence from a Randomized Need-Based Grant Program,” Discussion Paper 1393-11 (University of Wisconsin, 2011).

62. Amanda Pallais, "Taking a Chance on College: Is the Tennessee Education Lottery Scholarship a Winner?” Journal of Human Resources 44, no. 1 (2009): 199-222.

63. C. Kirabo Jackson, “A Little Now for a Lot Later: An Evaluation of a Texas Advanced Placement Incentive Program,” Journal of Human Resources 45, no. 3 (2010): 591-639.

64. Susan M. Dynarski, “Loans, Liquidity and Schooling Decisions” (Harvard University, 2005). 65. Donald E. Heller, "The Impact of Loans on Student Access," in The Effectiveness of Student Aid Policies: What the Research Tells Us, edited by Sandy Baum, Michael McPherson, and Patricia Steele (New York: The College Board, 2008), pp. 39-68. 
66. U.S. Government Accountability Office, "Challenges in Estimating Federal Subsidy Costs," GAO-05-874 (Government Printing Office, September 29, 2005). This report estimated that subsidized Stafford loans cost just four cents per dollar of loans disbursed through the federal direct loan program, while unsubsidized Stafford Loans provided a net gain to the government of nearly six cents for every dollar disbursed.

67. Jesse Rothstein and Cecilia Rouse, "Constrained after College: Student Loans and EarlyCareer Occupational Choices," Journal of Public Economics 95, no. 1-2 (2011): 149-63. 68. Erica Field, "Educational Debt Burden and Career Choice: Evidence from a Financial Aid Experiment at NYU Law School," American Economic Journal: Applied Economics 1, no. 1 (2009): 1-21.

69. Shlomo Benartzi and Richard H. Thaler, "Heuristics and Biases in Retirement Savings Behavior," Journal of Economic Perspectives 21, no. 3 (2007): 81-104.

70. Baum and Ma, Trends in College Pricing 2011(see note 5).

71. Ibid.

72. Christopher Avery and Thomas J. Kane, "Student Perceptions of College Opportunities: The Boston COACH Program," in College Choices: The Economics of Where To Go, When To Go, and How To Pay for It, edited by Caroline M. Hoxby (University of Chicago Press, 2004), pp. $355-94$.

73. U.S. Government Accountability Office, Higher Education: Improved Tax Information Could Help Families Pay for College, Report to the Committee on Finance, U.S. Senate, GAO12-560 (Government Printing Office, 2012). 
74. Stephanie Riegg Cellini and Claudia Goldin, "Does Federal Student Aid Raise Tuition? New Evidence on For-Profit Colleges," Working Paper 17827 (Cambridge, Mass: National Bureau of Economic Research).

75. Larry Singell and Joe Stone, "For Whom the Pell Tolls: The Response of University Tuition to Federal Grants-in-Aid,” Economics of Education Review 26 (2007): 285-95; Michael McPherson and Morton Schapiro, Keeping College Affordable: Government and Educational Opportunity (Washington: Brookings Institution, 1991).

76. Lesley J. Turner, “The Incidence of Student Financial Aid: Evidence from the Pell Grant Program" (Columbia University, Department of Economics, January 2012). 